\title{
The Sky and Sustainable Tourism Development: A Case Study of a Dark Sky Reserve Implementation in Alqueva
}

\author{
AUREA L. O. RODRIGUES ${ }^{1}$, APOLÓNIA RODRIGUES ${ }^{2 \star}$ and DEIDRE M. PEROFF ${ }^{3}$ \\ ${ }^{1}$ CPES, Lisbon, Portugal \\ ${ }^{2}$ Genuineland, Évora, Portugal \\ ${ }^{3}$ North Carolina State University, Raleigh, NC, USA
}

\begin{abstract}
This paper shows the development of a tourism product in a destination that uses the night sky as its main source of attraction. Using this innovative product has helped to create a distinctive image, which is likely to attract a more diverse range of visitors and has assisted in improving economic, social and environmental sustainability. First, we present an overview about sustainable tourism and the sky as a tourism resource followed by a case study, in Portugal, that illustrates the potential of Dark Sky activities for tourism development in rural regions. Copyright (C) 2014 John Wiley \& Sons, Ltd.
\end{abstract}

Received 1 September 2011; Revised 26 November 2013; Accepted 9 December 2013

KEY WORDS light pollution; sustainable tourism; rural tourism; Portugal; Alqueva; Dark Sky Reserve

\section{INTRODUCTION}

While there has been a growing awareness of air, water and land pollution over the last few years, references to light pollution have been less common. Light pollution is caused by the excessive use of artificial light. The International Dark Sky Association (IDA, 2011) defines it as 'Any adverse effect of artificial light including "sky glow" glow, trespass, mild confusion, decreased visibility at night'. It prevents city dwellers from viewing stars in the night sky, interferes with astronomical observation, disrupts ecosystems (Hölker, Wolter, Perkin, \& Tockner, 2010; Kyba, Ruhtz, Fisher, \& Holker, 2011) and has adverse effects on health. IDA has been developing some initiatives to create awareness about this issue, one of these being the creation of Dark Sky Reserves. Most of these are being created in the USA and Canada, but some are being established in Europe, e.g. the International Dark Sky Reserve, Galloway, Scotland, UK, and the Hotogaby International Dark Sky Park in Hungary. In Alqueva, Alantejo, Portugal, there is also a project in progress. Alqueva is based around an artificial lake some $83 \mathrm{~km}$ long with a lakeside extending to about $1160 \mathrm{~km}$ and covering six municipalities. The lake and surrounding area have a huge potential for tourism development. With the implementation of the Alqueva Dark Sky Reserve, the region intends to preserve the natural environment, promote the sustainable use of electric power, implement sustainable development measures and develop a distinct tourism offer.

The Dark Sky Reserve tourism program is based on activities geared toward the enjoyment of the stars and the night landscape. It is aimed at diversifying the tourism offer and promoting a distinct and unique destination image helped by the fact that there is no similar project in southern Europe. The absence of light pollution also helps to preserve

*Correspondence to: Apolónia Rodrigues, Genuineland, Évora, Portugal. E-mail: aurea108@gmail.com the biodiversity of the region. Recognition of the fact that the night sky should be preserved and could be used as a tourist resource is set out in point 9 of the 'Starlight Declaration in Defense of the Night Sky and the Right to Starlight' (La Palma Declaration, 2007): ${ }^{1}$

Among others, tourism can become a major instrument for a new alliance in defense of the quality of the nocturnal skyscape. Responsible tourism can and should take on board the night sky as a resource to protect and value in all destinations. Generating new tourist products based on the observation of the firmament and the phenomena of the night, opens up unsuspected possibilities for cooperation among tourism stakeholders, local communities, and scientific institutions.

In this paper, we will present a case study that shows how the development of an innovative tourism product in a destination can help to create a distinctive image that attracts diversified tourism markets and yet still allow for the creation of a clear commitment toward economic and environmental sustainability. An immediate result has been a reduction in energy bills and an improvement in the visitor economy through the opening up of new markets.

First, we provide an overview of sustainable tourism and the sky as a tourism resource, and then, we present the case study and some conclusions.

\footnotetext{
${ }^{1}$ Prepared in 2007 by the participants of the International Conference in Defence of the Quality of the Night Sky and the Right to Observe the Stars meeting in La Palma, Canary Islands, Spain, on 19 and 20 April 2007, jointly with the representatives of United Nations Educational, Scientific and Cultural Organization (UNESCO), United Nations World Trade Organisation, International Astronomical Union (IAU), United Nations Environment Programme - Convention on Migratory Species, Council of Europe, Secretariat of the Convention on Biological Diversity, Man and the Biosphere, European Commission and Ramsar Convention; see www. starlight2007.net
} 


\section{SUSTAINABLE TOURISM}

In the last few years, there has been a growing interest in the adoption of sustainable tourism practices by a significant number of consumers (Fletcher, 2009; Williams \& Ponsford, 2008; Holden, 2008). For Harns (2010), it is increasingly clear that tourists and travelers are beginning to demand sustainable tourism options and communities are opening up amazing partnerships with the tourism sector. According to the Brundtland (1987) report, sustainable tourism development

meets the needs of present tourists and host regions while protecting and enhancing opportunities for the future. It is envisaged as leading to management of all resources in such a way that economic, social and aesthetic needs can be fulfilled while maintaining cultural integrity, essential ecological processes and life support systems.

In 2004, the United Nations World Trade Organisation added in its conceptual definition of sustainable tourism:

the guidelines and management practices are applicable to all types of tourism including mass tourism and the various niche tourism segments. Sustainable principles refer to environmental, economic and socio-cultural, and a suitable balance must be established between these three dimensions to guarantee its long-term sustainability.

Quental and Lourenço (2012) searched scientific references to sustainable development in ISI Web of science and found about 3.334 papers in different research areas, with most of them citing the Brundtland report, but the authors did not refer directly to the papers that are concerned with tourism literature. Although, in recent years, sustainable development has become a key issue for tourism destination planners and managers (Ruhanen, 2008), it has led to an increasing interest in academia about the concept and its application to the tourism sector. However, there is no agreement about the definition (Butler, 1991; Lélé, 1991; Sharpley, 2000; Hitchcock \& Willard, 2009; Elkington, 2004). Consequently, the notion has sometimes been understood as an ideology and point of view rather than an exact operational definition (Buckley, 1996; Clarke, 1997; Swarbrooke, 1998; Hardy \& Beeton, 2001; Saarinen, 2006; Ruhanen, 2008). On the basis of the analysis of the tourism literature, Saarinen (2006) identified three traditions of ideas about sustainable tourism development:

(1) The resource-based tradition: This idea implies an objective and measurable limit or stage of growth at which there is no room for any more individuals in a certain environment. Tourism causes impacts, but in order to achieve further growth and development, individuals and actors will have to cope with the environment in a new and better way, such as by altering their behavior or number, but not primarily the resource that is used.

(2) The activity-based tradition: It refers to tourism-centric approaches in development discussions, focusing more on the needs of tourism as an economic activity. In research, it originates from ideas similar to the notion of product life cycle. The tourism area cycle of evolution proposed by Butler (1980) describes the change process of a destination from the early exploration and involvement stages through the development and consolidation stages, and finally to the stagnation stage. According to Butler, every tourism area has a limit to its growth, and the stagnated situation implies that this limit has been reached. The element that limits growth, referred to in the model as carrying capacity, is depicted as a relatively static zone that controls the scale of development in a specific environment.

(3) The community-based tradition: This idea implies that sustainability can be defined through a negotiation process, which indicates that the limits of growth are socially constructed (Jamal \& Getz, 1999; Raymond \& Brown, 2007; Choi \& Sirakaya, 2005). As a social construct, sustainability refers to the maximum levels of the known or perceived impacts of tourism that are permissible in a certain time-space context before the negative impacts are considered to be too disturbing from the perspectives of specific social, cultural, political or economic actors who possess sufficient power over the chosen indicators and criteria (Saarinen, 2006). In this perspective, hosts are empowered in development discourses and practices (Friedman, 1992; Chambers, 1997; Jensen, 2010). For Saarinen (2006), in the end, in this perspective, the limits of tourism are associated ontologically with power relations in a certain context. With the empowerment of communities, the growth in tourism is defined in a way that is more beneficial for the local people.

For Horobin and Long (1996), differing perceptions and interpretations among stakeholders make the translation of the concept into meaningful actions difficult, which is further influenced by the imbalance in weight and power in decisionmaking among stakeholders. According to Mowforth and Munt (1998: 103), 'the debate is currently not one whether local communities should be involved in the development of their areas, but how they should be involved and whether "involvement" means "control". For Butcher (2008), the communities living around conservation areas are best placed to manage the environment in a fashionable way. Brohman (1996) argued that local and small-scale initiatives are a partial antidote to national development schemas on a grander scale.

For Coccosis (1996, in Hannam \& Knox, 2010), in Europe, certain areas have been singled out for sustainable tourism development such as coastal areas, islands and urban and rural areas. But even if many rural areas in Europe face problems of depopulation, such as coastal areas, some rural areas face a large number of tourists superior than the number of residents that can contribute to environmental degradation through overcrowding, pollution, waste and infrastructure development. Sustainable development in rural areas can contribute to environmental conservation and increased public awareness of the values of resources. 


\section{THE SKY AS A TOURISM RESOURCE}

The desire to find and lose ourselves in the stars is ancient. Like so many others inhabitants of this planet over the eons, we use the stars to navigate far away and to find our way back home. (IDA, http://www. darksky.org/)

With the evolution of technology, the development of space tourism has gained in importance. There are several ways for space tourism to be developed (Table 1), from space flights, the first tourist being Dennis Tito (Cater, 2009), to land-based space tourism, and the latter is the focus of our study. According to Jafari (2007:56),

tourism - both in theory and practice-actually becomes an important means connecting the two domains of earth and sky, allowing people to experience diversity and richness of life here and to literally touch the stars above, soon for in-situ space visits.

For Crouch (2001), terrestrial space tourism probably began with the movement of astronomical observers to different locations to better observe certain astronomical phenomena such as eclipses and the movements of planets. Nowadays, there are organized visits, such as cruises and tours, to see the launch of shuttle flights, and there are some 'space tourism tour operators' emerging and creating a large range of diversified products (Cater, 2009). But the preservation of starlight as a world heritage phenomenon is very recent.

The preamble of the UNESCO 'Convention Concerning the Protection of the World Cultural and Natural Heritage' (1972) states that 'the deterioration or disappearance of any item of the cultural or natural heritage constitutes a harmful impoverishment of the heritage of all the nations of the world'.
In 1994, this theme appears again in the 'Universal Declaration of Human Rights for Future Generations':

Persons belonging to future generations have the right to an uncontained and undamaged Earth, including pure skies; they are entitled to its enjoyment as the ground of human history of culture and social bonds that make each generation and individual a member of the human family.

UNESCO has undertaken activities to safeguard cultural heritage in relation to astronomy through the 'Astronomy and World Heritage' project launched by the World Heritage Centre in 2003 (in Cameron, 2007). UNESCO took up this theme again in 2005

The sky our common and universal heritage, is an integral part of the environment perceived by humanity. Humankind has always observed the sky either to interpret it or to understand the physical laws that govern the universe. The interest in astronomy has had profound implications for science, philosophy, religion, culture and our general conception of the universe.

In 2009, with the UNESCO's 'Kazan resolution', it was defined as tangible astronomical heritage. For the main categories of 'tangible astronomical heritage', see Table 2.

Following this definition of the principles of tangible astronomical heritage, conforming to Article 3 of the 1972 Convention, regions are now allowed to submit nominations for cultural and natural sites, relating to astronomical heritage, for inscription on the World Heritage List, to identify and delineate properties situated on its territory and that the existing World Heritage criteria, as indicated in the Operational Guidelines, can be used for the assessment of outstanding universal value of the cultural and natural properties (UNESCO, 2009). For Cameron (2007), the protection of starlight is necessary as its impact on humanity has been expressed in words of religion, art, literature, science, philosophy, business and travel.

Table 1. Types of space tourism

\begin{tabular}{|c|c|c|c|}
\hline Form & & Type & Examples \\
\hline Astro-tourism & $\begin{array}{l}\text { Beyond Earth orbit } \\
\text { In Earth orbit }\end{array}$ & $\begin{array}{l}\text { Lunar and Martian voyages } \\
\text { Orbital flights }(350 \mathrm{~km}) \\
\text { Sub-orbital flights }(100 \mathrm{~km})\end{array}$ & $\begin{array}{l}\text { Not yet available } \\
\text { 'Trips to ISS' (Space Adventures) } \\
\text { Virgin Galactic }\end{array}$ \\
\hline $\begin{array}{l}\text { Atmospheric space } \\
\text { tourism }\end{array}$ & & $\begin{array}{l}\text { High-altitude jet flights }(20 \mathrm{~km}) \\
\text { Weightless flights }\end{array}$ & $\begin{array}{l}\text { MIG } 31 \text { flights (Russia) } \\
\text { Zero G Corporation (USA/Russia) }\end{array}$ \\
\hline \multirow[t]{4}{*}{$\begin{array}{l}\text { Terrestrial space } \\
\text { tourism }\end{array}$} & In specific places & $\begin{array}{l}\text { Observatories } \\
\text { Cruises }\end{array}$ & $\begin{array}{l}\text { There are about } 500 \text { observatories in } 31 \text { countries } \\
\text { 'Eye on the sky' oriented program of Astro } \\
\text { Cruises are found on board of Celebrity, } \\
\text { Clipper, Cruise West and others } \\
\text { Dark Sky Sites fall into the 'International Dark } \\
\text { Sky Community', 'International Dark Sky Park' } \\
\text { and 'International Dark Sky Reserve' }\end{array}$ \\
\hline & & $\begin{array}{l}\text { Simulations } \\
\text { 'Edu-trainement' }\end{array}$ & $\begin{array}{l}\text { Flight simulator release (Kennedy Space Centre) } \\
\text { Spacewalker (Gold Coast, Australia)National } \\
\text { Space Centre (Leeds, UK) }\end{array}$ \\
\hline & $\begin{array}{l}\text { Space tourism developed } \\
\text { in nonspecific locations }\end{array}$ & $\begin{array}{l}\text { Travel related to space tourism } \\
\text { Experience related to cyberspace }\end{array}$ & $\begin{array}{l}\text { Travel to observe eclipses } \\
\text { Virtual travel and spatial Games with space } \\
\text { environment }\end{array}$ \\
\hline & & Popular culture & Movies related to space travel \\
\hline
\end{tabular}

Source: Cater (2009; www.darksky.org, www.caminhodasestrelas.com). 
Table 2. Tangible astronomical heritage and the main categories of tangible astronomical heritage

Definition of tangible astronomical heritage

Tangible astronomical heritage is the material evidence relating to astronomy and representations of astronomy. Astronomy is characterized by the observation and coherent interpretation of celestial objects and events from the earliest stages of human evolution through the modern world, including but not confined to the history of contemporary science. It forms part of the efforts by all human beings to comprehend the observable world or universe - the cosmos within which they dwell and to understand their place within it.
Principal categories of tangible astronomical heritage

Observatories as 'scientific monuments'

Material representations of the results of astronomical observations and contextual understanding: constructions, architecture and urbanism related to applied astronomy and/or bearing astronomical information

Properties whose design and/or landscape setting have significance in relation to celestial objects or events

Monuments, sites and cultural landscapes related to the history of astronomy and/or human cultural practices related to astronomy Sites related to space exploration

Source: Kazan Resolution (UNESCO, 2009).

In the next part of the paper, we present a case study that illustrates an initiative that has two objectives: to minimize light pollution and develop a tourism product, with the night sky as the main resource.

\section{Case study: Implementation of the Dark Sky Reserve in Alqueva, Portugal}

Case studies provide the opportunity to share innovative ideas, business (best) practices, professional issues and lessons learned from delivering tourism and hospitality services and activities. They are an invaluable source of knowledge for educators, professionals and researchers alike. The case study uses various information sources to focus on a specific situation over a given period. This technique is very useful for studying complex realities (Nykiel, 2007) and is widely used in studies related to tourism and education (Beeton, 2005). According to Veal (2005), a case study approach presents the following advantages: (i) it has the ability to aim the issue addressed in the study as a whole, instead of abstracting a limited set of preselected features; (ii) it has the ability to put people, organizations, events and experiences in their historical and social contexts; (iii) its use of multiple methods - triangulation - are implicit and seen as an advantage; (iv) a case study, or a limited number of them, is a way of collecting information more manageably when resources are limited; (v) flexibility in the strategy of data collection allows researchers to adapt their research strategies as well as their procedures for collecting; and (vi) it is not generalized to a population in general.

The case study presented in this paper seeks to examine how a region can use an initiative linked to light pollution mitigation to diversify the tourism offer.

This work was developed and based on a holistic approach (Yin, 2004), and the period of research was from December 2009 to September 2011. The following sources of data were used:

- Semi-structured interviews (Altinay \& Paraskevas, 2008; Jennings, 2005; Jordan \& Gibson, 2004) with some local actors (Table 3); the local entrepreneurs were chosen for their role in the implementation of the project, using the snowball technique, i.e. using referrals made from among the people involved in the project (Biernacki \& Waldorth, 1981).
Table 3. Stakeholders interviewed

\begin{tabular}{lc}
\hline Interviewed & $\begin{array}{c}\text { Number of the } \\
\text { interviewee }\end{array}$ \\
\hline $\begin{array}{l}\text { President of a nonprofit rural } \\
\text { tourism organization }\end{array}$ & 1 \\
$\begin{array}{l}\text { Tourism entrepreneur } \\
\text { (owner of a rural lodging unit) }\end{array}$ & 2 \\
Tourism entrepreneur (food and beverage) & 3 \\
$\begin{array}{l}\text { Owner of a rural lodging unit and member } \\
\text { of a rural tourism organization }\end{array}$ & 4 \\
Tourism entrepreneur (tourist activities) & 5 \\
A volunteer of the Dark Sky project & 6 \\
\hline
\end{tabular}

- Documentation collected from various sources such as the Internet, regional bodies and local libraries.

- Participant observation: this technique is recognized as the most appropriate method to obtain data on interactions since it allows for the recording of behavior in situ (Tucker \& Lynch, 2004; Jorgensen, 1989). The main author conducted the participant observation. Participant observation was carried out during activities related to the implementation of the project, namely in meetings and activities concerning the development of the Dark Sky Reserve, undertaken between December 2009 and September 2011. The researcher participated in the meetings, as an observer, and this provided an opportunity to unify and comprehend the fragmented data gathered from other sources.

According to Barghini and Medeiro (2006), it may seem paradoxical to talk about light pollution in the midst of apparently more serious events - such as greenhouse gas emissions, destruction of the ozone layer, and air, water and soil pollution (Figure 1). Generally, we consider light to be a symbol of purity, safety and life and not a source of environmental contamination (Narisada \& Schreuder, 2004).

However, for thousands of years, natural environments have been developed without artificial lighting. In the past few years, there has been increasing interest in this issue. Most of that interest has come from astronomers concerned about the excessive use of lighting at night, which seriously affects the ability to observe the night sky. Light pollution obscures nighttime stars from urban residents (Chalkias, Petrakis, Psiloglou, \& Lianou, 2006) and interferes with 


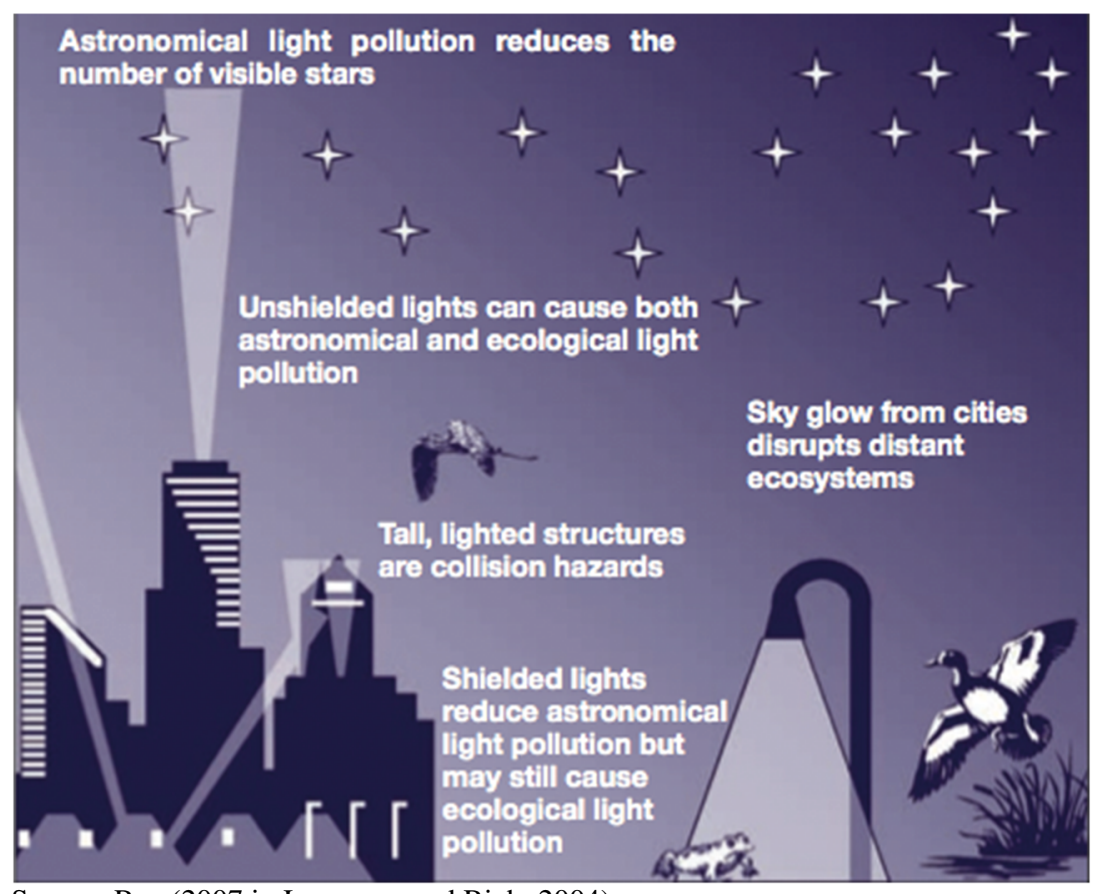

Source: Ros (2007 in Longcore and Rich, 2004).

Figure 1. Ecological and astronomical light pollution is caused by lights at night. Source: Ros (2007, in Longcore \& Rich, 2004). This figure is available in color online at wileyonlinelibrary.com/journal/jtr

astronomical observation (Pedani, 2004), and, like any other form of pollution, it disrupts ecosystems (Bourgeois et al., 2009). Many species in both terrestrial and aquatic ecosystems use the level of ambient light to regulate their metabolism, growth and behavior (Kyba et al., 2011). The sky glow caused by artificial lighting from urban areas disrupts this natural cycle and has been shown to impact the behavior of organisms, even many kilometers away from the light sources. It also has adverse effects on human health (Pauley, 2004a, 2004b; Kerenyib, Pandulab, \& Feuerb, 1990). According to Falchi et al. (2011), the International Agency for Research on Cancer has recently added to the list of group 2A (probably carcinogenic to humans) shift work that involves circadian disruption (Straif et al., 2007). As seen, circadian disruption is also induced by light exposure at night, and light at night is becoming a public health issue (Pauley, 2004a, 2004b; Stevens, 2009). Light pollution has to be recognized as a hazard to our environment and our health and not, as commonly believed, as just a problem for astronomers (Falchi et al., 2011). This view is supported by the recent resolution of the American Medical Association, House of Delegates (2009) where it is said that light pollution is a public health hazard.

Light pollution can be divided into two main types: (i) annoying light that intrudes on an otherwise natural or lowlight setting; and (ii) too much light (usually indoors), which leads to discomfort and adverse health effects. According to Narisada and Schreuber (2004), all external lights cause light pollution. Sky glow is the result of light that is projected upward. Generally, this is caused by poorly designed or inappropriate lighting. However, this can also occur when the light is projected upward on purpose.

Another major contribution to the diffusion of light is light that is directed at objects and reflected by them. Road surfaces, glass buildings and monuments reflect much incidental light, and the reflection will generally shine upward. Much of this lighting is used in an appropriate way, since the goal of illumination is to make objects visible. This can only be performed through direct lighting. Since early 1980s, a global movement of dark sky (IDA) emerged, with people interested in developing a campaign to reduce the amount of light pollution.

The IDA was founded in 1988, by Dr. David L. Crawford and his colleague Dr. Tim Hunter, to address the growing problem of light pollution. Over the past 20 years, IDA has grown from two members and volunteers to a membership of over 11000 with full-time staff support. It is now the leading worldwide organization trying to combat light pollution.

The association has published a number of papers, guides and a newsletter highlighting the topic of light pollution and has also organized events, popular meetings, programs and features, such as the Fixture Seal of Approval Program or the International Dark Sky Communities, International Dark Sky Parks and International Dark Sky Reserves Programs. Through their International Dark Sky Places program, IDA and its partners certify locations with exceptional nightscapes. There are now about 18 Dark Sky Reserves around the world, and most of them are in Canada and the USA (Table 4). In 2009, there was a growing interest in developing a Dark Sky Reserve in a region of Portugal, Alqueva, Alentejo, where most of the area has no light pollution (Figure 2) and most of the light pollution that does occur comes from the public service lighting of streets and buildings.

The interior of Alentejo has a large rural area that has, in recent years, seen the development of a program of rural and cultural tourism. However, the largest artificial lake in Europe, Lake Alqueva, has recently been created in the 
Table 4. List of Dark Sky Reserves

\begin{tabular}{|c|c|c|c|}
\hline Continent & Country & Place & Date of designation \\
\hline \multirow[t]{15}{*}{ North America } & Canada & Cypress Hills, Saskatchewan/Alberta & 2004 \\
\hline & Canada & Beaver Hills, Alberta & 2006 \\
\hline & Canada & Point Pelee National Park, Ontario & 2006 \\
\hline & Canada & Mont Mégantic Observatory, Quebec & $\begin{array}{c}2005 \text { (first international Dark } \\
\text { Sky Preserve) }\end{array}$ \\
\hline & Canada & McDonald Creek Provincial Park, British Columbia & 2003 \\
\hline & Canada & Manitoulin Island, Ontario & 2008 \\
\hline & Canada & $\begin{array}{l}\text { Bruce Peninsula Fathom Five National } \\
\text { Marine Park, Ontario }\end{array}$ & 2009 \\
\hline & Canada & Torrance Barrens, Ontario & $\begin{array}{l}1999 \text { (first Canadian Dark } \\
\text { Sky Preserve) }\end{array}$ \\
\hline & Canada & Grasslands National Park Saskatchewan & 2009 \\
\hline & Canada & Kouchibougauc National Park, New Brunswick & 2009 \\
\hline & Canada & Mt. Carleton Provincial Park, New Brunswick & 2009 \\
\hline & USA & Lake Hudson State Recreational Area, Michigan & - \\
\hline & USA & Natural Bridges National Monument, Utah & $\begin{array}{c}2007 \text { (first international Dark } \\
\text { Sky Park) }\end{array}$ \\
\hline & USA & Potawatomi Wildlife Park, Wisconsin & 2003 \\
\hline & USA & Cherry Springs State Park, Pennsylvania & - \\
\hline \multirow[t]{3}{*}{ Europe } & Scotland & Galloway Forest Park, Dumfries and Galloway & 2009 \\
\hline & $\begin{array}{l}\text { Czech Republic } \\
\text { and Poland }\end{array}$ & Jizera Dark Sky Park, Jizera Mountains & $\begin{array}{l}2009 \text { (first bilateral } \\
\text { dark sky park) }\end{array}$ \\
\hline & Hungary & Zselic Landscape Protection Area & 2009 \\
\hline
\end{tabular}

Source: www.darksky.org

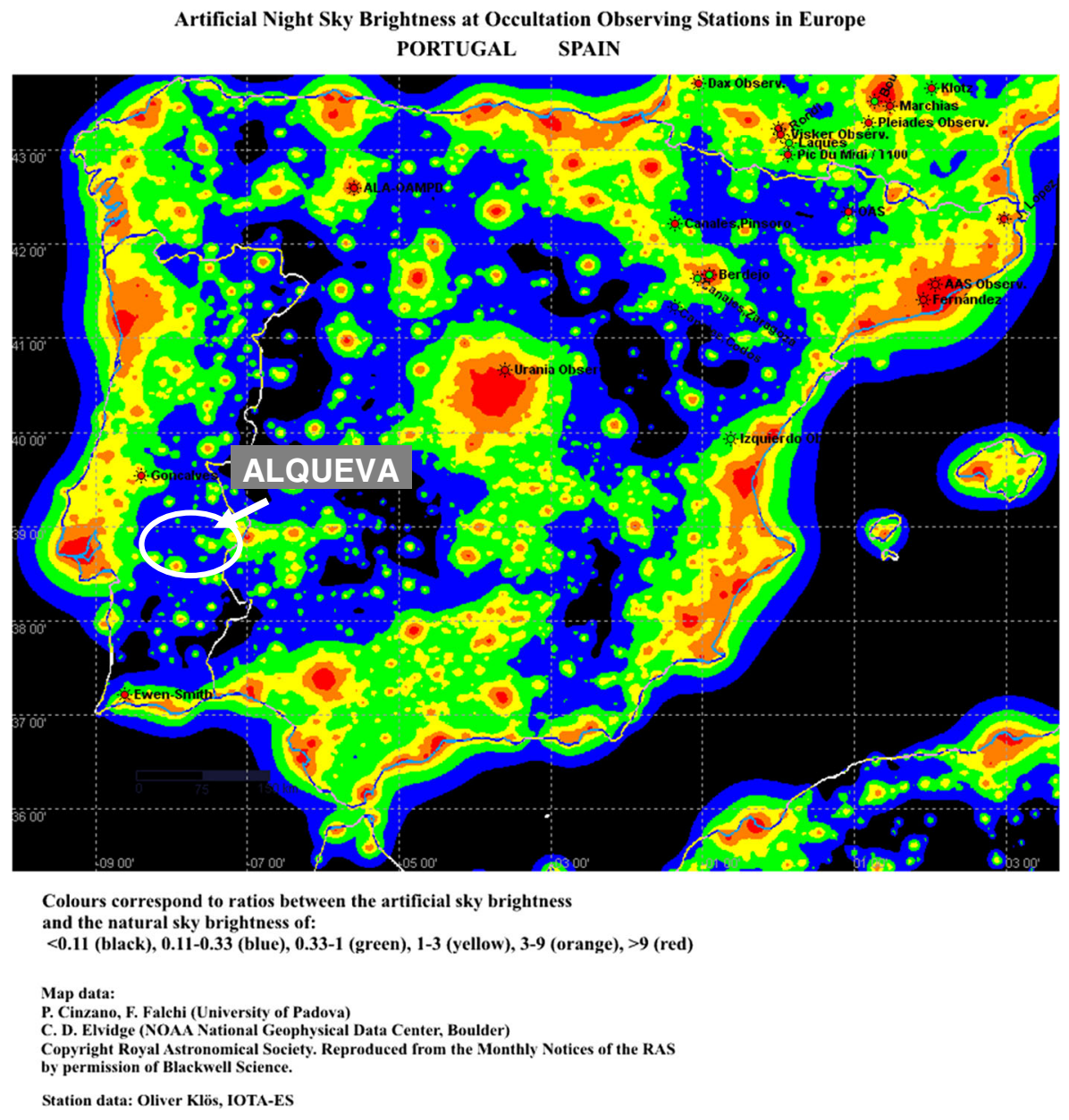

Source: http://www.iota-es.de/light_pollution/Portugal_Spain.gif

Figure 2. Artificial night sky in Portugal and Spain. This figure is available in color online at wileyonlinelibrary.com/journal/jtr 
Table 5. Main benefits of Dark Sky implementation in Alqueva through tourism and sustainable development

\begin{tabular}{ll}
\hline Dark Sky Reserve & \multicolumn{1}{c}{ Tourism development } \\
\hline Sustainable development & $\begin{array}{l}\text { Creation of a distinctive tourist image from other rural } \\
\text { destinations in Portugal } \\
\text { Rwareness of tourism entrepreneurs for maximization } \\
\text { of economic and environmental sustainability } \\
\text { Development of tourism activities based on the night sky, } \\
\text { such as 'Under the Stars Walks', horseback riding at night } \\
\text { and observation of the sky with astronomers, among others }\end{array}$ \\
\hline $\begin{array}{l}\text { Education/awareness of all stakeholders in the region on } \\
\text { the negative impacts of excessive lighting }\end{array}$ &
\end{tabular}

region. The lake resulted from the construction of a dam and has a length of $83 \mathrm{~km}$, which is distributed along the municipalities of Moura, Mourão, Portel, Barrancos, Reguengos de Monsaraz and Alandroal. The lake has an area of $250 \mathrm{~km}^{2}$. Given its size, state officials decided, in 2008, to set up a new entity to manage the emerging destination: Tourism Land of the Great Lake Alqueva - Alentejo (TGLA). Integrated strategies were prepared for the development of tourism in the region, and partnerships were seen as a fundamental tool for delivery. According to Bramwell and Pomfret (2007), the basis for the development of tourism in lake areas is complex and results from the interaction between society, environment and the various local actors. The development is more effective if it results from an interaction between the several actors. Awareness of this issue has prompted the TGLA to foster the development of partnerships as a means of securing sustainable tourism development and to generate the creation of innovative products.

With this in mind, a partnership in Alqueva was created with the Alentejo Network of Village Tourism, Genuineland (a nonprofit association of rural tourism entrepreneurs that has responsibility for coordinating the process), the TGLA, the Empresa de Desenvolvimento e Infra-estruturas do Alqueva, SA (the company that manages the dam) and the Alentejo Regional Coordination and Development Commission. The aim of the partnership is to implement the Agenda for Sustainable and Competitive Tourism through the development of the Alqueva Dark Sky Reserve. In addition to the core partnership, several working groups have been created to involve other main stakeholders such as universities, regional and local public authorities (municipalities and others), national and international experts, national authorities with competencies in tourism and agriculture, nonprofessional associations for development and astronomy, agencies for regional development and Portuguese professionals.

The region consists almost entirely of small villages and suffers heavily from rural depopulation. Tourism, however, is an integral part of daily life for these communities. There is also growing interest in investing in the area due to its perceived potential as an attractive tourism destination. Local people want tourism to increase to help improve income levels. As a consequence, many villages such as Monsaraz, Telheiro and Portel have based their development strategies around tourism. Other villages and communities with less potential also need the income from tourism but currently have more limited tourism services and are not yet as well organized.

This region does have some light pollution (Figure 2), but as most of the sources of pollution (street and public building lighting) are managed by six public institutions involved in the project, it is likely that change can be effected more quickly.

The reserve has two main objectives: (i) to implement a sustainable use of light strategy; and (ii) to maximize the tourism opportunities of the region (Table 5) by creating new tourism products linked to the night sky and the development of area-based marketing with the involvement of residents, local and regional stakeholders and the scientific community.

The project is financed by the public organizations involved and by private businesses such as hotels/guest houses and restaurants.

Since 2009, $€ 39000$ has been spent on the project. Most of the work required is carried out by volunteers and the employees of one key partner organization. The project is based on a low level of financial commitment to help ensure its sustainability and continuity.

There is a relatively low budget for marketing and promotion as the main strategy has been to generate media attention through Dark Sky Reserve designation and the innovative approaches being adopted. To date, this has proven to be extremely successful with good media coverage in Portugal, the UK, Germany and the USA. Media interest has in itself generated positive interest from tour operators who have been marketing the product to their customers.

The project also has the support of the national tourism organization, Turismo de Portugal, which is very important at this level.

It is intended to create an area with the provision of activities 24 hours a day, but not based on traditional evening activities such as bars and nightclubs. The programmes of activity are centered around contact with the land on a sensory basis where the evening is geared to the enjoyment of starlight and the landscape itself, which takes on another life after dark (1, see Table 3).

The Dark Sky Reserve is a tourism product that can make a difference in the destination since there is no similar project in southern Europe. At the same time, it may 
increase the demand from 'culturally creative' and slow tourism tourists, which seek not only such products as good value quality accommodation but fine food, wine and culture (2, see Table 3).

The quality of the night sky in the area was certified in 2011 by the Starlight Foundation when it was designated as the first Starlight Tourism Destination ${ }^{2}$ in the world. It was so designated because it has a high-quality tourism offer, which has been organized to receive and support astro-tourists.

The tourism partnership referred to above has created a route (the Dark Sky Route), which is carefully regulated and sets out a set of rules for businesses wanting to integrate into the project. These rules relate to the need to adapt services to accommodate the needs of the astrotourist. Most of the current visitors are amateur astronomers who prefer to do their stargazing independently. As a result, the route, on the basis of a scheme prepared in association with the Portuguese Amateur Astronomers Association, is training tourism entrepreneurs to guide and develop activities with tourists who have limited or no knowledge of stargazing.

At present, all the actors engaged in the Dark Sky Route are trying to develop strategies to reduce light pollution and improve the tourism offer.

One of the biggest threats to the overall initiative is the planned increase of lodging units around the lake even though developers recognize that the quality of the sky is a benefit for their businesses.

In the last few years, there has been a growing demand for niche markets in rural tourism. According to Clarke (2005), many tourists nowadays seek 'doing' activities in rural places. Those activities are not directly connected with the local culture but with what is possible to do in those areas, like night activities such as night walks and some activities related to niche markets interested in space tourism based on land. At the same time, other tourism movements are evolving such as 'slow tourism', where the place is appreciated in a way that the visitor has an opportunity to become part of the destination through contact with the community and the area at a pace appropriate to the retention of local culture and the place as a whole.

The differentiation on the basis of the physical attributes of the destination (the night sky, rural landscape and the lake) and the reputation (activities carried out in the context of sustainable development) of the region may be the foundations for distinguishing the region from other rural destinations (Huybers \& Bennet, 2002; Hall, 2002). This case presents what Saarinen (2006) designated the community-based tradition of sustainable tourism development. With the creation of the Dark Sky Reserve, communities were provided with information about sustainable development, enabling them to establish their own criteria for determining acceptable levels of light pollution in their part of the region.

\footnotetext{
${ }^{2}$ Starlight Destinations are visitable places characterized by excellent quality for the contemplation of starry skies and the practice of tourist activities based on this resource (Starlight Foundation, 2011).
}

A common theme, such as a Dark Sky Route, makes it easier to create common goals that are better understood by communities. In addition to the visual benefit of reducing light pollution, electricity bills for municipalities, local people and tourism businesses are reduced by limiting light output at night.

When the economic benefits of sustainable actions can be proven so convincingly, it becomes so much easier to implement new ideas among stakeholders even though they might not be directly involved in tourism.

There are not many places in Europe where a similar project could be replicated, but on the basis of the resources of the regions, there could be other thematic concepts that might achieve similar benefits.

The success of the Dark Sky Alqueva experience could be centered on the following key factors (European Union, 2013:117):

- The budget is not the most important element of a program.

- Creativity, imagination, investment in applied research and innovation are the most critical success factors.

- It is fundamental to anticipate future trends, but this requires proper research.

- A real partnership based on trust is likely to work and can bring important added value.

- Continuing the innovation process, having a new idea every day and keeping the interest in the program going at the partnership level and in the host community are of major importance.

\section{CONCLUSIONS}

According to Page and Connel (2006), one of the main issues in rural tourism management is that the activity is dependent on an attractive natural and culturally interesting environment. This reinforces the need to ensure that sustainable approaches to tourism development are adhered to. The sustainability of the starlight is a subject that has just recently started to gain attention. Even the awareness that it is necessary to preserve tangible astronomical heritage is very recent. In 2009, the IAU and UNESCO designated that year as 'The International Year of Astronomy' to help the citizens of the world to rediscover their place in the universe through the daytime and nighttime sky and to encourage a personal sense of wonder and discovery.

The process started in 2005 when UNESCO created IAU's Working Group on Astronomy and World Heritage to identify, safeguard and promote cultural properties connected with astronomy, and in 2009, the components that could be integrated into the definition of tangible astronomical heritage were defined.

Other associations such as the Dark Sky initiative, established over 20 years ago, have also worked toward the preservation of the sky. The implementation of a Dark Sky Reserve allowed a destination to work on sustainable development issues related to light pollution to benefit the local population and help develop tourist products that support and grow sustainable tourism development. 
With correct integration and promotion, it could be a distinctive feature that helped attract a wider range of visitors from different segments of the tourism market. According to Ros (2007), unpolluted starlight must be maintained for future generations, and humanity needs to preserve the sky in order to

- enjoy the sky and feel emotional about it;

- promote positive feelings toward astronomy and toward science in general;

- help people to discover and taste the adventure of a new knowledge by means of simple observations using the naked eye, binoculars, amateur telescopes or public observatories;

- impress upon humanity the beauty of natural phenomena; and

- look at the sky to rediscover the stories of our ancestors.

In the last few years, there has been a growing interest in rural destinations for those taking holidays in Europe. Each year, new rural destinations appear on the market, increasing competition.

To face this challenge, the regions must develop new tourism products and strategies to survive among the increasing competition. At the same time, there is an increasing awareness of sustainable development from both tourism destinations and tourists. A preserved/conserved environment improves the quality of life for residents and helps to deliver a more competitive tourism product.

In this paper, a strategy that is (i) based on sustainable development principles, (ii) has sought to engage initially with the local population and (iii) can be used as a tourism resource has been presented. Both the community and the visitor economy can benefit from this initiative. The process is continuing but has one main underlying constraint, i.e. the initial high level of initial investment needed to replace existing lighting systems with new less polluting and more efficient lights.

In resolving this issue, there are two key factors: (i) the main changes to existing lighting infrastructure that are needed are the responsibility of just six public institutions, and if a large number of companies and organizations were involved, this would be far more difficult to achieve; and (ii) the region has a tradition of achieving tourist development on the basis of the involvement of several stakeholders in a network strategy (Rodrigues \& Rodrigues, 2009).

The cooperation of the public and private sectors, as well as community involvement in a bottom-up approach, is crucial in achieving a successful and sustainable destination product (Rodrigues, Kastenholz, \& Rodrigues, 2007). Even if the advantages are well known and this theme has been vastly documented in scientific literature, it is not easy for communities to be involved in projects that use a bottomup approach.

In Alqueva, it worked, but more research is needed to understand how this process can be facilitated elsewhere. Future research should focus not just on what has been realized but also on what has failed and why it has failed. However, this case study shows that small local initiatives related to sustainable development are easier to implement if they are integrated in a protected area.
Protected areas could have as main focus different thematic approaches. In this case, the main focus was centered on light pollution reduction. Future research should also focus on how other themes could lead communities to more easily undertake sustainable initiatives.

\section{REFERENCES}

Altinay L, Paraskevas A. 2008. Planning Research in Hospitality and Tourism. Butterworth-Heinemann: Oxford.

American Medical Association, House of Delegates. 2009. Resolution 516: Advocating and Support for Light Pollution Control Efforts and Glare Reduction for Both Public Safety and Energy Savings, http://www.ama-assn.org/ama1/pub/upload/mm/475/a-09-ref-comm-e-annotated.pdf.http://www.amaassn.org/ama1/pub/upload/mm/475/a-09-ref-comm-e-annotated. pdf. (accessed June 2011)

Barghini A, Medeiro B. 2006. A iluminação artificial sobre o meio ambiente. Revista Brasileira de Ciências Ambientais 5: 4-16.

Beeton S. 2005. The case study in tourism research: A multi-method case study approach. In Tourism Research Methods, Integrating Theory with Practice. Ritchie, B, Burns, P, Palmer, C (eds). CABI Pub: London; 37-49.

Biernacki P, Waldorth D. 1981. Snowball Sampling Problems and Techniques of Chain Referral Sampling. Sociological Methods \& Research 10(2): 141-163.

Bourgeois S, Gilot-Fromont E, Viallefont A, Boussamba F, Deemd S. 2009. Influence of Artificial Lights Logs and Erosion on Leatherback Sea Turtle Hatchling Orientation at Pongara National Park, Gabon. Biological Conservation 42(1): 85-93.

Bramwell B, Pomfret G. 2007. Planning for Lake and Lake Shore Tourism: Complexity, Coordination and Adaptation. Anatolia: An International Journal of Tourism and Hospitality Research 18(1): 43-66.

Brohman J. 1996. New Directions for Tourism in the Third World. Annals of Tourism Research 23: 48-70

Buckley R. 1996. Sustainable Tourism: Technical Issues in Information Needs. Annals of Tourism Research 23(4): 925-928

Brundtland G. 1987. Our common future. United Nations: Oslo.

Butler R. 1980. The concept of a tourist area cycle of evolution: implications for management of resources. The Canadian Geographer 24(1):5-12.

Butcher J. 2008. The myth of agency through community participation in ecotourism. In Tourism Development: Growth, Myths and Inequalities. Burns, P, Novelli, M (eds). CABI Pub: Oxfordshire; 11-28.

Butler R. 1991. Tourism, Environment, and Sustainable Development. Environmental Conservation 18(3):201-209.

Cameron F. 2007. The right to starlight under international law. In Starlight: A Common Heritage. Marin, C, Jafari, J (eds). Starlight Initiative, Instituto de Astrofísica de Canárias (IAC): Spain; 237-247.

Cater C. 2009. Steps to Space: Opportunities for Astrotourism. Tourism Management 36(6):838-845.

Chalkias C, Petrakis M, Psiloglou B, Lianou M. 2006. Modelling of Light Pollution in Suburban Areas Using Remotely Sensed Imagery and GIS. Journal of Environmental Management $\mathbf{7 9}$ (1): 57-63.

Chambers R. 1997. Whose Reality Counts? Putting the First Last. Intermediate Technology Pub: London

Choi H, Sirakaya E. 2005. Measuring Residents' Attitude toward Sustainable Tourism: Development of Sustainable Tourism Attitude Scale. Journal of Travel Research 43(4): 380-394.

Clarke J. 1997. A Framework of Approaches to Sustainable Tourism. Journal of Sustainable Tourism 5: 224-233.

Clarke J. 2005. Effective marketing for rural tourism. In Rural Tourism and Sustainable Businesses. Hall D, Kirkpatrick I, Mitchell M (eds). Channel View Publishers: UK; 87-103. 
Crouch G. 2001. The Market for Space Tourism: Early Indications. Journal of Travel Research 40: 213-219

Elkington J. 2004. Enter the triple bottom line. In The Triple Bottom Line: Does It All Add Up? Henriques, A, Richardson, J (eds.) Earthscan: London.

European Union. 2013. Programme Dark Sky Alqueva (PT), case 19. In Evaluation and Exchange of Good Practices in the Tourism Sector to Stimulate Growth and Jobs in the EU. Annex B - good Practice Cases. Pp. 109-118, Kent, UK: CSES.

Falchi F, Cinzano P, Elvige C, Keth D, Haim A. 2011. Limiting the Impact of Light Pollution on Human Health, Environment and Stellar Visibility. Journal of Environmental Management 92: 2714-2722

Fletcher R. 2009. Ecotourism Discourse: Challenging the Stakeholder's Theory. Journal of Ecotourism 8(3): 264-285

Friedman J. 1992. The Earthscan Reader in Sustainable Development. Earthscan Pub: London.

Hall D. 2002. Branding and national identity: The case of Central and Eastern Europe. In Destination Branding, Creating the Unique Destination Proposition. Morgan, N, Pritchard, A, Pride, R (eds). Butterworth-Heinemann Publishers: UK; 87-105.

Hannam K, Knox D. 2010. In Understanding Tourism: A Critical Introduction. SAGE Pub: UK.

Hardy A, Beeton R. 2001. Sustainable Tourism: An Australian Perspective. Chastwood: Butterworth-Heinemann.

Harns E. 2010. Sustainable tourism: From nice to have to need to have. In Trends and Issues in Global Tourism 2010. Conrady, R, Back, M (eds). Manheim: Springer.

Hitchcock D, Willard M. 2009. The Business Guide to Sustainability - Practical Strategies and Tools for Organizations. (2nd ed), London: Earthscan.

Holden A. 2008. In Environment and Society (2nd ed). Routledge: UK.

Hölker F, Wolter C, Perkin EK, Tockner K. 2010. Light Pollution as a Biodiversity Threat. Trends Ecology and Evolution 25: 681-682.

Horobin H, Long J. 1996. Sustainable Tourism: The Role of the Small Firm. International Journal of Contemporary Hospitality Management 8(5): 15-19.

Huybers T, Bennet J. 2002. In Environmental Management and Competitiveness of Nature-based Destinations. Edward Elgar Publishing: London.

IDA. 2011. Definition of light pollution, http://www.darksky.org/ (accessed June 2011)

Jafari J. 2007. Terrestrial outreach - Living the stardome on Earth. In Starlight: A Common Heritage. Marín, C, Jafari J (eds). Starlight Initiative, Instituto de Astrofísica de Canárias (IAC): Canary Islands, Spain; 55-59.

Jamal T, Getz D. 1999. Community Roundtables for Tourism Related Conflicts: The Dialectics of Consensus and Process Structures. Journal of Sustainable Tourism 7(3-4): 290-313.

Jennings G. 2005. Interviewing: A focus on qualitative techniques. In Tourism Research Models, Integrating Theory with Practice. Ritchie, B, Burns, P, Palmer, C (eds). CABI Pub: UK; 99-119.

Jensen O. 2010. Social Mediation in Remote World Tourism Locations - The Significance of Social Ties between Local Guides and Host Communities in Sustainable Development. Journal of Sustainable Tourism 18(5): 615-633.

Jordan F, Gibson H. 2004. Let your data do the talking: Researching the solo travel experiences of British and American Woman. In Qualitative Research in Tourism: Ontologies, Epistemologies and Methodologies. Phillimore, J, Goodson, L (eds). Routledge: UK.

Jorgensen D. 1989. Participant observation, A methodology for human studies. SAGE: Thousand Oaks: California, USA.

Kerenyib A, Pandulab E, Feuerb G. 1990. Why the Incidence of Cancer Is Increasing: The Role of Light Pollution. Medical Hypotheses 33(2): 75-78.
Kyba C, Ruhtz T, Fisher J, Holker F. 2011. Cloud Coverage Acts as an Amplifier for Ecological Light Pollution in Urban Ecosystems. PLoS One 6(3): 681-682.

Lélé S. 1991. Sustainable Development: A Critical Review. World Development 19:607-621.

Longcore T, Rich C. 2004. Ecological light pollution. Frontiers in Ecology and the Environment 2(4):91-198.

Mowforth M, Munt I. 1998. Tourism and Sustainability: New Tourism in the Third World. Routledge: London.

Narisada K, Schreuber D. 2004. In Light Pollution Handbook. Springer: UK.

Nykiel R. 2007. In Handbook of Marketing Research, Methodologies for Hospitality and Tourism. Haworth Press: NY.

Page S, Connell J. 2006. Tourism: A modern Synthesis. Thomson Learning: London, UK.

Pauley S. 2004a. Lighting for the Human Circadian Clock: Recent Research Indicates that Lighting Has Become a Public Health Issue. Medical Hypotheses 33(2): 588-596.

Pauley SM. 2004b. Lighting for the Human Circadian Clock: Recent Research Indicates that Lighting Has Become a Public Health Issue. Medical Hypotheses 63: 588-596.

Pedani M. 2004. Light Pollution at the Roque de los Muchachos Observatory. New Astronomy 9(8): 641-650.

Quental N, Lourenço J. 2012. References, Authors, Journals and Scientific Disciplines Underlying the Sustainable Development Literature: A Citation Analysis. Scientometrics 90:361-381.

Raymond C, Brown G. 2007. A spatial method for assessing resident and visitor attitudes towards tourism grouth and development. Journal of Sustainable Tourism 15(5):520-540.

Rodrigues A, Rodrigues A. 2009. Turismo e Inovação em Espaços Rurais: Estudo de caso da da Rede Europeia de Turismo de Aldeia. Revista Turismo e Análise 20(1): 35-47.

Rodrigues A, Kastenholz E, Rodrigues A. 2007. Networks in rural tourism and their impact on sustainable destination development: The case of the European Network of Village Tourism. Proceedings Advances in Tourism Economics 2007. S. André, Alentejo, Portugal.

Ros R. 2007. The importance of observation in astronomy education and the need for clear and non-polluted skies. In Starlight: A Common Heritage. Marin, C, Jafari, J (eds). Starlight Initiative, Instituto de Astrofísica de Canárias (IAC): Spain; 121-129.

Ruhanen L. 2008. Progressing Sustainable Debate: A Knowledge Management Approach to Sustainable Tourism Planning. Current Issues in Tourism 11(5): 429-455.

Saarinen J. 2006. Traditions of Sustainability in Tourism Studies. Annals of Tourism Research 33(4): 1121-1140.

Sharpley R. 2000. Tourism and Sustainable Development: Exploring the Theoretical Divide. Journal of Sustainable Tourism 8: 1-19.

Stevens RG. 2009. Light-at-Night, Circadian Disruption and Breast Cancer: Assessment of Existing Evidence. International Journal of Epidemiology doi: 10.1093/ije/dyp178(accessed June 2011).

Straif K, Baan R, Grosse Y, Secretan B, El Ghissassi F, Bouvard V, Altieri A, Benbrahim-Tallaa L, Cogliano V. 2007. Carcinogenicity of Shift-work, Painting, and Fire-fighting. Lancet Oncology 8(12): 1065-1066.

Swarbrooke J. 1998. Sustainable Tourism Management. CABI Publishing: New York.

Tucker H, Lynch P. 2004. Host-guest dating: The potential of improving the costumer experience thought host-guest psychographic matching. In Hospitality, Tourism and Lifestyle Concepts Implications for Quality Management and Consumer Satisfaction. Thyme, M, Laws, E (eds). Haworth Hospitality Press: New York.

UNESCO. 1972. Convention concerning the Protection of the World Cultural and Natural Heritage. http://www.unesco.org/ new/en/unesco/ (accessed June 2011). 
UNESCO. 2005. Proclamation of 2009 as International Year of Astronomy, UNESCO General Conference 33rd Session http:// whc.unesco.org/en/astronomy (accessed June 2011).

UNESCO. 2009. Final report from the meeting "Astronomy and World Heritage: Across Time and Continents" held in Kazan, Tatarstan, Russian Federation, Aug 19-23, 2009, http://tinyurl. com/352s4xehttp://tinyurl.com/352s4xe (accessed June 2011).
Veal AJ. 2005. Business Research Methods: A Managerial Approach. Pearson Addison Wesley: Frenchs Forest.

Williams P, Ponsford I. 2008. Confronting Tourism's Environmental Paradox: Transitioning for Sustainable Tourism. Futures 41(6): 396-404.

Yin R. 2004. Case Study Research: Design and Methods (2nd edn). Sage Publishing: Beverly Hills, CA. 